\title{
Electoral Disinformation: Looking Through the Lens of Tsek.ph Fact Checks
}

\author{
Yvonne T. Chua and Jake C. Soriano
}

Elections are fertile ground for disinformation. The 2019 midterm elections, like the 2016 presidential election, buttress this observation. This ugly side of electoral contests is documented by Tsek.ph, a pioneering collaborative fact-checking initiative launched by three universities and eleven newsrooms specifically for the midterms. Its repository of fact checks provides valuable insights into the nature of electoral disinformation before, during and after the elections. Clearly, electoral disinformation emanates from candidates and supporters alike, on conventional (e.g., speeches and sorties) and digital (e.g., social media) platforms. Its wide range of victims includes the media no less.

Keywords: Philippines, elections, Tsek.ph, fact-checking, journalism

If there was one bright spot in the May 13, 2019 Philippines midterm elections, that certainly would be the groundbreaking collaborative factchecking initiative undertaken by media and academia to help counter the escalation of political disinformation in the country.

Launched February 11, the eve of the campaign period, Tsek.ph was instrumental in addressing newsroom rivalry and other barriers that for years had deterred newsrooms from working alongside one another, not even after the Philippines was dubbed "Patient Zero" of the modern disinformation age as early as 2016 (Rappler, 2018).

During the presidential election that year, an insidious, sophisticated network of disinformation players emerged on social media, particularly on Facebook, dominated by the camp of then candidate and now president Rodrigo Duterte (Bradshaw \& Howard, 2017). Disinformation would worsen and take various forms under the Duterte presidency, with the Philippines quickly and consistently making it to the list of countries identified as being engaged in state-led social media manipulation "Freedom on the Net 2017: Manipulating social media to undermine democracy," 2017; Freedom on the Net 2018: The rise of digital authoritarianism," 2018).

Modeled on successful fact-checking collaborations during elections elsewhere-France, Brazil and Indonesia, among them-Tsek.ph brought into its fold eleven newsrooms, national and regional alike (ABS-CBN, Baguio Midland Courier, CLTV 36, DZUP 1602, Interkasyon, Mindanews, 
The Philippine Star, Philstar.com, Probe Productions, Rappler and Vera Files), and the three universities (Ateneo de Manila University, De la Salle University and the University of the Philippines) ("About Tsek.ph," n.d.).

The 131 fact checks Tsek.ph partners singly or jointly produced in the three months that followed provide valuable insights into the shape and form, as well as the perpetrators and victims of disinformation the country was awash in the run-up, during and after the midterms.

More than half of the total 131 claims flagged by Tsek.ph were usergenerated content that spread on social media.

A doctored photo supposedly showing a massive Hugpong ng Pagbabago rally is one good example (University of the Philippines Journalism Department, 2019c). It was carved out of two crudely edited images-that of the administration coalition candidates in its Pampanga sortie in 2019 against that of a crowd on the National Mall in Washington D.C. attending U.S. President Donald Trump's inauguration in 2017-to fake the number of attendees. The fake photo went viral on Facebook and was tracked by social media analytics tool Crowdtangle before being taken down by its creators.

However, the other half of the claims debunked by Tsek.ph were false or out-of-context statements made by candidates and other public figures themselves, in televised debates, public forums, speeches, campaign ads and even curricula vitae.

For example, then candidate and now senator Maria Imelda "Imee" Marcos falsely claimed first in her curricula vitae that she graduated from

\section{Who were the sources of mis- and disinformation?}

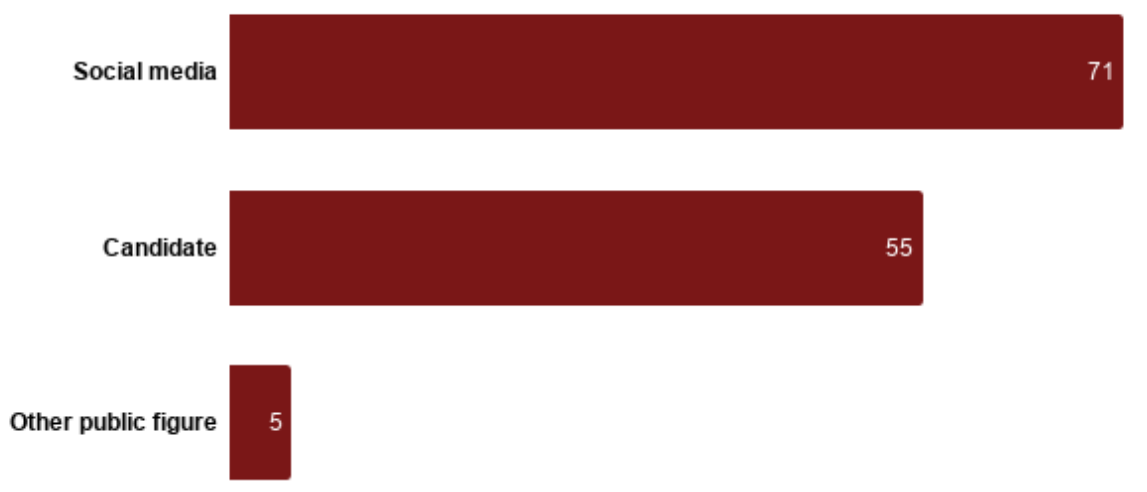

Fig. 1. Sources of mis- and disinformation. 
Princeton University (Viray \& Rappler, 2019; The Philippine Star, 2019), the University of the Philippines College of Law (Rappler, 2019a; Viray, 2019) and a boarding school in California (Rappler, 2019c), and then repeated in a television interview her dubious graduation from Princeton (Viray \&Rappler, 2019). Her claims were fact-checked by Tsek.ph partners and debunked by the institutions themselves.

On several occasions, certain Senate hopefuls made false and misleading claims directly on social media, through their official pages or accounts.

For example, losing candidates Lorenzo "Larry" Gadon and Glenn Chong made false claims against pre-election surveys and research organizations in their Facebook posts. Gadon made wrong assertions in an online video about Social Weather Stations (SWS) and Pulse Asia sample sizes (Vera Files, 2019a), while Chong posted about topping an online poll, without stating the poll was informal and not scientific (University of the Philippines Journalism Department, 2019b).

Facebook was the preferred social media platform of candidates in the elections, perhaps owing to its massive use by the public, many of whom use "free basics." Of the 62 Senate hopefuls certified by the Commission on Elections (Comelec), at least 30 had official Facebook pages that regularly posted content.

\section{Where were deceptive claims made?}

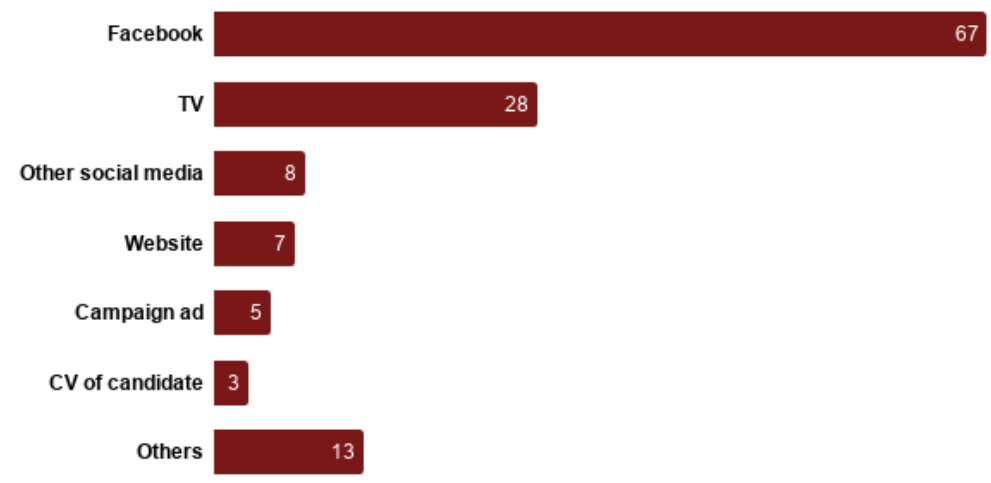

Fig. 2 Where deceptive claims were made.

Tsek.ph documented how state-run and mainstream media amplified election-related disinformation, some of which can be traced to the candidates or their press releases.

In March, two months before the midterms, SWS disowned a purported February survey supposedly showing then candidate, and eventual winner, 
Christopher Lawrence "Bong" Go had placed third for the period (Arguillas, 2019).

The information came from a media release from Go's very own campaign bureau, which newsrooms, including the state-run Philippine News Agency ("Bong Go surges into solo 3rd place in latest SWS poll," 2019), published, apparently without double-checking (University of the Philippines Journalism Department, 2019c).

While hard to establish if election-related disinformation propelled certain candidates to victory and crushed the chances of others, the pattern that emerges from Tsek.ph data show those who were most targeted indeed lost their bids.

\section{Who were most targeted by mis- or disinformation?}

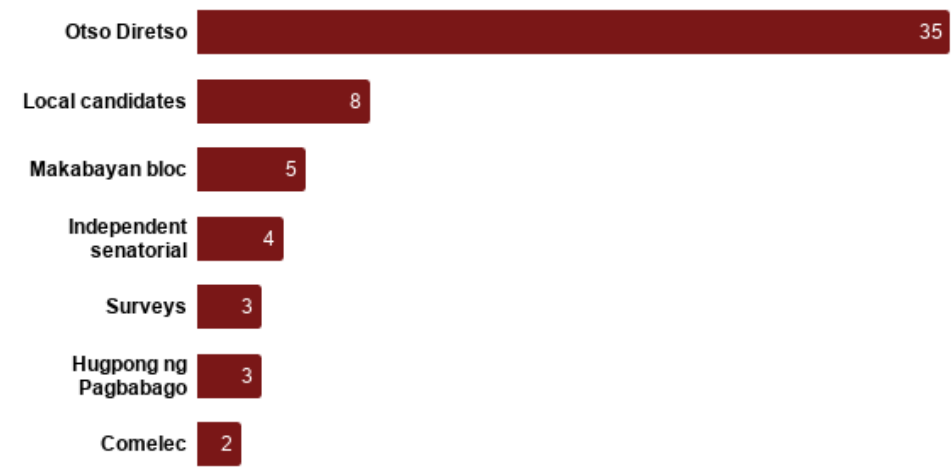

Fig. 3 Most targeted by mis- and disinformation.

The opposition Otso Diretso slate-notably Manuel "Mar" Roxas II and Paolo Benigno "Bam" Aquino IV who both based on pre-election surveys had the biggest chances of winning-was the most targeted by mis- and disinformation in the midterms. No Otso Diretso member won their Senate bids (Cabico, 2019).

Roxas was a frequent victim of repurposed photos, a common strategy used by disinformation creators.

Months before the polls, multiple Facebook pages posted a photo of the Senate hopeful riding a padyak (cycle rickshaw) with a misleading caption criticizing his supposed gimmickry (University of the Philippines Journalism Department \& Vera Files, 2019). The photo was taken during the run up to the 2010 elections, not 2019 as the posts suggest.

Roxas was also the subject of a false blog post claiming he had left the opposition slate (Rappler, 2019b). 
Even after he lost his Senate bid, Roxas still became the subject of false news, when an old altered photo spread on social media showing a woman offering him a rope tied into a noose (University of the Philippines Journalism Department, 2019m). The fake photo first went viral in the runup to the 2016 presidential elections, and has already been debunked.

Meanwhile, Aquino was a frequent victim of fake social media quote cards, including one falsely claiming that he said poor people should be fed leftovers or scavenged food (University of the Philippines Journalism Department, 2019a).

Certain local candidates who were targeted by fake disqualification content on social media up to the eve and day of the polls are a distant second, being victims eight times to Otso Diretso's 35. Three candidates, one from Cagayan de Oro city in Mindanao (Gallardo, 2019) and two from Pangasinan province in Luzon (Rappler, 2019e), were victims of fabricated Comelec resolutions supposedly disqualifying them. In Antique, a province in the Visayas, a different deception strategy was at play; a spurious website called Philippine News Organization claimed a congressional hopeful has withdrawn their candidacy (Rappler, 2019f).

In contrast, the administration Hugpong ng Pagbabago slate was victimized by mis- and disinformation only three times, our analysis of Tsek.ph fact checks further shows.

Altered photos, or real ones but posted with out-of-context comments, and fake infographics are the most common types of false or misleading content related to the elections posted on social media.

Sen. Ramon "Bong" Revilla on election day was targeted by a post which altered his photo to falsely show him flipping the bird, one of the few times a member of the administration slate was a disinformation victim (University of the Philippines Journalism Department, 2019i).

Tsek.ph flagged infographics purporting to be survey results, or falsely showing invented or out-of-context quotes to attack certain candidates.

Equally disturbing, because it sought to undermine the integrity of the elections, was a hoax video showing a pre-shaded ballot (Vera Files \& University of the Philippines Journalism Department, 2019) that went viral and merited mention in the bill filed by Senate President Vicente "Tito" Sotto III seeking to combat "false content" online by penalizing its creators (Anti-False Content Act, 2019).

Most of the claims and online content flagged by Tsek.ph-six in tenare outright false. Most of the rest mislead or take out important context, but are still deceptive and inaccurate.

Tsek.ph used five ratings to classify claims: "Accurate" for claims that are demonstrably factual and true; "False" for claims demonstrably contrary 
to available facts; "Misleading" for claims that give a vague or different impression; "No basis" for claims that cannot be verified or fact-checked; and "Needs context" for claims that need more facts or clarification because they may be taken out of context.

\section{What are the forms of deceptive content on social media?}

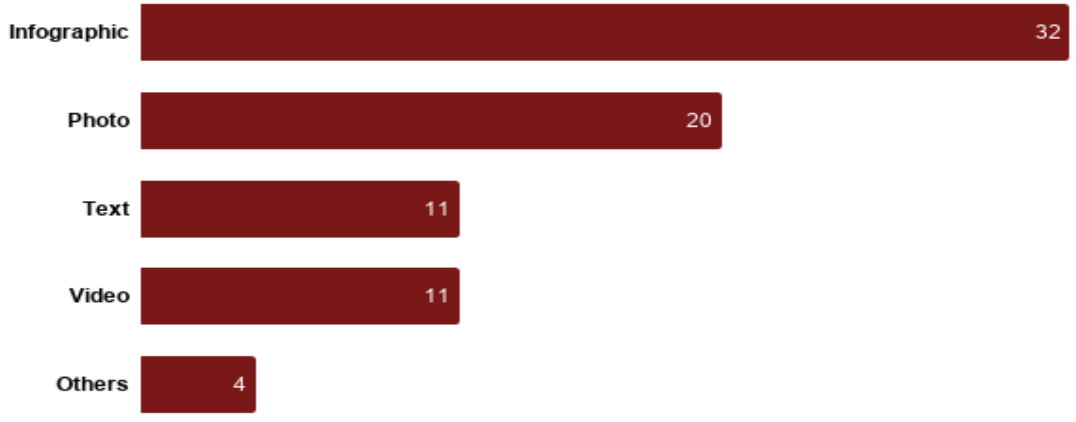

Fig. 4. Forms of deceptive content on social media.

An ad by former police chief and now senator Ronald "Bato" dela Rosa claimed credit for reducing the country's volume of index crimes by 49 percent, but gave no time frame for the drop it highlighted and provided no clear basis for comparison (University of the Philippines Journalism Department, 2019e).

The midterm elections evidently provided an occasion for red tagging or red-baiting, defined as "the act of attacking or persecuting as a Communist or as communistic" ("red-baiting," n.d.).

One such victim was the progressive Makabayan bloc, which fielded several party-list groups in the House of Representatives and saw itself targeted by false or misleading content during the elections.

There were indications the attacks were state-sponsored. On election eve, a false post claiming Makabayan party-list groups had been disqualified appeared on a Facebook account claiming to be the police force of Iloilo City as well as four other accounts claiming to be Philippine army reservists in Mindanao (University of the Philippines Journalism Department, Vera Files, Rappler, \& The Philippine Star, 2019). The "fake news" somehow gained credence because a disqualification case against the Makabayan bloc was indeed pending before the Comelec but had not been decided.

On election day, two Facebook accounts supposedly associated with the Agusan del Norte police, published misleading posts red tagging a number 


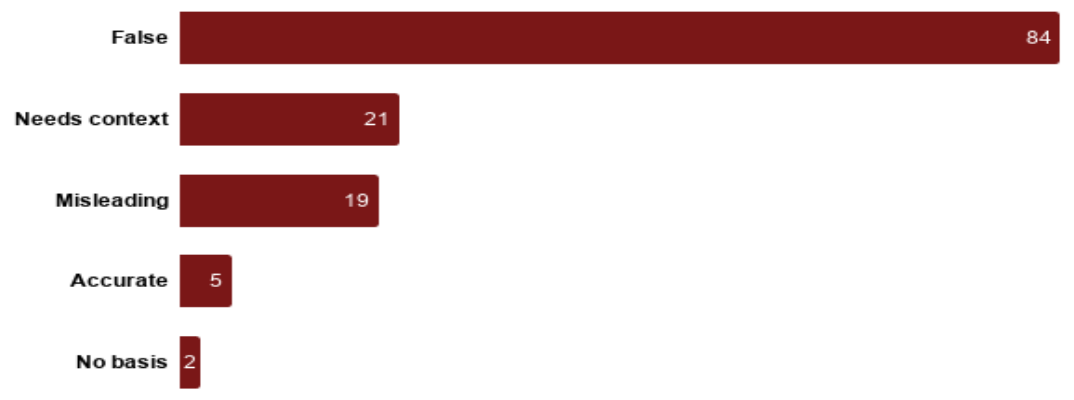

Fig. 5 Ratings given to deceptive claims.

of party-list groups; more than half of those in the list were not party-list groups or were not running at all (Vera Files, 2019b).

On election day at polling precincts within Metro Manila, voters also saw policemen distributing the Philippine National Police's (PNP) official publication tying Bayan Muna and Kabataan party-list groups to the outlawed Communist Party of the Philippines (CPP) and its armed wing, the New People's Army (NPA) (DZUP 1602 \& University of the Philippines Journalism Department, 2019). The publication is also available on the national police's Facebook page.

Duterte himself also took to redtagging. In a speech three days before the elections, the president falsely claimed that Otso Diretso candidate Lorenzo "Erin" Tañada III was previously elected senator and had defended communists in court (University of the Philippines Journalism Department, 2019k).

But disinformation during the midterm elections also strove to resemble legitimate news: infographics were manipulated, and headlines and stories made up and attributed to big media. The biggest victim was television network and Tsek.ph partner ABS-CBN. Other victims were TV network News 5 (University of the Philippines Journalism Department, 2019g), leading broadsheets Philippine Daily Inquirer (University of the Philippines Journalism Department, 2019h) and Philippine Star (University of the Philippines Journalism Department, 2019f), and a popular daily in Iloilo province, the Daily Guardian (University of the Philippines Journalism Department, 2019j).

A fabricated screenshot showed ABS-CBN News purportedly reporting that anti-Otso Diretso Facebook accounts would be suspended. No such article was posted on the official ABS-CBN website (Rappler, 2019d). 
Creators of the false Makabayan disqualification claim appeared to have spent some time brainstorming their disinformation product; its final form, a photo, bore the logos of both the Comelec and television network ABS-CBN to feign legitimacy (University of the Philippines Journalism Department, Vera Files, Rappler, \& The Philippine Star, 2019).

In sum, disinformation was pervasive in the midterm elections, purveyed mostly on Facebook, largely through images and, on numerous occasions, in the guise of news. Opposition candidates and progressive groups were the most targeted, the former a frequent victim of recycled and misleading to downright false information and the latter, chiefly of redtagging. 


\section{References}

About Tsek.ph, (n.d.). Retrieved from https://tsek.ph/about

Anti-False Content Act. S. 9, 18th Cong (2019).

Arguillas, C. (2019, March 8). Bong Go now number 3 in alleged "SWS survey;" SWS says it's not theirs. Minda News. Retrieved from https://www.mindanews.com/top-stories/2019/03/bong-go-nownumber-3-in-alleged-sws-survey-sws-says-its-not-theirs/

Bong Go surges into solo 3rd place in latest SWS poll. (2019, March 7). (2019, March 7). Philippine News Agency. Retrieved from https://www.pna.gov.ph/articles/1063902

Bradshaw, S., \& Howard, P. (2017). Troops, trolls and troublemakers: A global inventory of organized social media manipulation. Retrieved from http://comprop.oii.ox.ac.uk/wp-content/uploads/ sites/89/2017/07/Troops-Trolls-and-Troublemakers.pdf

Cabico, G. (2019, May 22). Opposition slate Otso Diretso suffers a resounding loss. Philstar Global. Retrieved from https://www.philstar.com/headlines/2019/05/22/1917758/opposition-slate-otsodiretso-suffers-resounding-loss

DZUP 1602, \& University of the Philippines Journalism Department. (2019, May 13). Accurate: PNP distributes publication red-tagging partylists. Retrieved from https://tsek.ph/article/accurate-pnpdistributes-publication-red-tagging-partylists

Freedom on the Net 2017: Manipulating social media to undermine democracy. Freedom House. (2017). Freedom on the Net 2017: Manipulating social media to undermine democracy. Washington, D.C. Retrieved from https://freedomhouse.org/sites/default/files/FOTN_2017_Final.pdf

Freedom on the Net 2018: The rise of digital authoritarianism.Freedom House. (2018). Freedom on the Net 2018: The rise of digital authoritarianism. Washington, D.C. Retrieved from https://freedomhouse. org/sites/default/files/FOTN_2018_Final\%20Booklet_11_1_2018.pdf

Gallardo, F. (2019, May 11). Comelec disqualification order vs CDO mayor Oscar Moreno spurious. Retrieved from https://tsek.ph/article/comelec-disqualification-order-vs-cdo-mayor-oscarmoreno-spurious

Rappler. (2018, June 23). Facebook's Katie Harbath on protecting election integrity [Video File]. Retrieved from https://youtu.be/dJ1wcpsOtS4

Rappler. (2019a, Feb. 20). False: Imee Marcos 'graduated cum laude from UP College of Law.' Retrieved from https://tsek.ph/article/false-imee-marcos-graduated-cum-laude-college-law

Rappler. (2019b, March 20). False: Mar Roxas 'leaves' Otso Diretso. Retrieved from https://tsek.ph/article/ false-mar-roxas-leaves-otso-diretso

Rappler. (2019c, March 22). False: Imee Marcos was 'class valedictorian' from California boarding school. Retrieved from https://tsek.ph/article/false-imee-marcos-was-class-valedictorian-californiaboarding-school

Rappler. (2019d, April 24). False: 'ABS-CBN news headline' on suspending anti-Otso Diretso Facebook accounts. Retrieved from https://tsek.ph/node/107

Rappler. (2019e, May 13). Amado Espino III and Jumel Espino,disqualified' in Pangasinan. Retrieved from https://tsek.ph/node/156

Rappler. (2019f, May 13). False: Exequiel Javier 'withdraws' congressional bid in Antique. Retrieved from https://tsek.ph/node/127 
Red-baiting. (n.d.). Merriam-Webster online. In Merriam Webster. Retrieved from https://www.merriamwebster.com/dictionary/red-baiting

The Philippine Star. (2019, March 5). Video: Imee's Princeton, UP degrees debunked. Retrieved from https://tsek.ph/article/video-imees-princeton-degrees-debunked

University of the Philippines Journalism Department. (2019a, March 14). Bong Go fan page distorts Bam Aquino food waste quote. Retrieved from https://tsek.ph/article/bong-go-fan-page-distorts-bamaquino-food-waste-quote

University of the Philippines Journalism Department. (2019b, March 16). Chong post about topping online poll needs context. Retrieved from https://tsek.ph/article/chong-post-about-toppingonline-poll-needs-context

University of the Philippines Journalism Department. (2019bc, March 16). Bong Go website references disputed SWS survey. Retrieved from https://tsek.ph/article/bong-go-website-referencesdisputed-sws-survey

University of the Philippines Journalism Department. (2019d, March 28). Trump inaugural photo used to fake Hugpong rally crowd. Retrieved from https://tsek.ph/article/trump-inaugural-photo-usedfake-hugpong-rally-crowd

University of the Philippines Journalism Department. (2019e, April 11). Bato ad on crime needs context. Retrieved from https://tsek.ph/article/bato-ad-crime-needs-context

University of the Philippines Journalism Department. (2019f, April 15). Pro-Marcos page misleads with old Philstar graphic. Retrieved from https://tsek.ph/article/pro-marcos-page-misleads-oldphilstar-graphic

University of the Philippines Journalism Department. (2019g, April 17). Duterte fan page posts altered News5 graphic. Retrieved from https://tsek.ph/article/duterte-fan-page-posts-altered-news5graphic

University of the Philippines Journalism Department. (2019h, May 6). FALSE: 'Inquirer story' on Gutoc threatening to jail netizens over life vest. Retrieved from https://tsek.ph/article/false-inquirerstory-gutoc-threatening-jail-netizens-over-life-vest

University of the Philippines Journalism Department. (2019i, May 12). FACT CHECK: No, this is not an ABS-CBN News story on a former Bulacan official. Retrieved from https://tsek.ph/article/fact-checkno-not-abs-cbn-news-story-former-bulacan-official

University of the Philippines Journalism Department. (2019j, May 13). FALSE: 'Daily Guardian post' on Gorricetas junking ally Biron. Retrieved from https://tsek.ph/article/false-daily-guardian-postgorricetas-junking-ally-biron

University of the Philippines Journalism Department. (2019k, May 13). Duterte claim vs Tañada false. Retrieved from https://tsek.ph/article/duterte-claim-vs-tanada-false

University of the Philippines Journalism Department. (2019l, May 13). Revillas raising middle finger after voting false. Retrieved from https://tsek.ph/article/revillas-raising-middle-finger-after-voting-false University of the Philippines Journalism Department. (2019m, May 24). Old Roxas viral photo manipulated post-election. Retrieved from https://tsek.ph/node/161 
University of the Philippines Journalism Department, \& Vera Files. (2019, March 19). Updated: Old Mar Roxas photo resurrected, misleads. Retrieved from https://tsek.ph/article/updated-old-mar-roxasphoto-resurrected-misleads

University of the Philippines Journalism Department, Vera Files, Rappler, \& The Philippine Star. (2019, May 13). Police, Army reservists share false disqualification claim vs Makabayan bloc. Retrieved from https://tsek.ph/article/police-army-reservists-share-false-disqualification-claim-vs-makabayanbloc

Vera Files, \& University of the Philippines Journalism Department. (2019, May 13). False: Viral online post on 'pre-shaded ballots.' Retrieved from https://tsek.ph/article/false-viral-online-post-pre-shadedballots

Vera Files. (2019a, Feb. 14). Gadon gets two things wrong in rant vs. SWS, Pulse Asia. Retrieved from https://tsek.ph/article/gadon-gets-two-things-wrong-rant-vs-sws-pulse-asia

Vera Files. (2019b, May 13). Alleged Agusan police FB pages mislead with post on NDF-backed 'partylists.' Retrieved from https://tsek.ph/article/alleged-agusan-police-fb-pages-mislead-post-ndfbacked-party-listsViray, P. (2019, March 7). Viral UP Law yearbook with Imee Marcos not from 1983. Retrieved from https://tsek.ph/article/viral-law-yearbook-imee-marcos-not-1983

Viray, P., \& Rappler. (2019, Feb. 13). Despite evidence, Imee Marcos insists she graduated from Princeton. Retrieved from https://tsek.ph/article/despite-evidence-imee-marcos-insists-she-graduatedprinceton

YVONNE T. CHUA is an associate professor of the University of the Philippines Journalism Department. She was a coordinator of the collaborative fact-checking initiative Tsek.ph during the 2019 Philippines elections. She obtained her master's degree in public management from the University of the Philippines. (corresponding author:ytchua@up.edu.ph)

JAKE C. SORIANO is a reporter of Agence France-Presse's Manila bureau where he produces fact checks. He was the editor of the collaborative fact-checking initiative Tsek.ph during the 2019 Philippines elections. He obtained his master's degree in public policy in development policy from the Australian National University. (corresponding author: jake.soriano@gmail.com) 
